\title{
Determinan Pemilihan Penggunaan Metode Kontrasepsi Jangka Panjang (MKJP) di Puskesmas Sungai Jingah
}

\author{
M. Bahrul Ilmi ${ }^{1}$, Nurul Indah Qariati $^{2}$, Rakhmi Hidayati ${ }^{3}$ \\ ${ }^{1-3}$ Program Studi S1 Kesmas UNISKA MAB Banjarmasin \\ Email: illmy1202@gmail.com
}

Submitted : 18/09/2020

Accepted: 01/10/2020

Published: 06/03/2021

\begin{abstract}
One of the strategies of the program implementation Plan is listed in its own KB construction of medium-term national (RPJMN) in 2015-2019 is a declining rate of population growth (LPP), decreasing the total birth rate (TFR) per WUS, increasing the use of contraception, decreased needs air-KB which is not met, the declining birth rate in teenagers ages 15-19 years, and decreased unwanted pregnancy of WUS (15-49 years). The scope of use of MKJP (Long-term Contraceptive Methods) is still low and poorly chosen by Couples of fertile Age (PUS) that only amounted to 9,3\% compared with hormonal contraception that is amounted to $88,5 \%$. The purpose of this research is to know the use of determinant Long-term Contraceptive Methods (MKJP) in the Puskesmas Sungai Jingah 2019. This research method using analytic survey with the use of cross sectional. The population is mothers who do visit KB acceptors from January to March 2019 totaled 237 acceptors. The sample in this research is the 70 respondents. Research instrument this is questionnaire with question form and interview. Data analysis with statistical tests test chi square. The desired confidence level is $90 \%(a=0,1)$. Research results showed the use of electoral parity with MKJP $(p=0,488)$, and support her husband with the use of MKJP $(p=0,003)$, statistically parity has no relationship with the use of Long-term Contraceptive Methods (MKJP). While the husband support the selection of Long-term use of Contraceptive Methods (MKJP). Advice for mom user KB is expected to play an active role in the efforts of the use of contraceptives, particularly long -term contraception.
\end{abstract}

Keywords : knowledge, parity, support the husband, selection of MKJP usage

\begin{abstract}
Abstrak
Salah satu strategi dari pelaksanaan program KB sendiri tercantum dalam Rencana Pembangunan Jangka Menengah Nasional (RPJMN) tahun 2015-2019 adalah menurunnya Laju Pertumbuhan Penduduk (LPP), menurunnya Angka Kelahiran Total (TFR) per WUS, meningkatnya pemakaian kontrasepsi, menurunnya kebutuhan ber-KB yang tidak terpenuhi, menurunnya angka kelahiran pada remaja usia 15-19 tahun, dan menurunnya kehamilan yang tidak diinginkan dari WUS (15-49 tahun). Cakupan penggunaan MKJP (Metode Kontrasepsi Jangka Panjang) masih rendah dan kurang dipilih oleh Pasangan Usia Subur (PUS) yaitu hanya sebesar 9,3\% dibandingkan dengan kontrasepsi hormonal yaitu sebesar $88,5 \%$. Tujuan penelitian ini mengetahui determinan pemilihan penggunaan MKJP di Puskesmas Sungai Jingah tahun 2019. Metode penelitian menggunakan survei analitik dengan penggunaan cross sectional. Populasi yang digunakan adalah ibu-ibu akseptor KB yang melakukan kunjungan dari bulan Januari-Maret 2019 berjumlah 237 akseptor. Sampel pada penelitian ini 70 responden. Instrumen penelitian ini adalah kuisoner dengan angket dan wawancara. Analisis data dengan uji statistik uji chi square. Tingkat kepercayaan yang diinginkan adalah $90 \%(a=0,1)$. Hasil penelitian menunjukan paritas dengan pemilihan penggunaan MKJP $(p=0,488)$, dukungan suami dengan pemilihan penggunaan $\operatorname{MKJP}(p=0,003)$, secara statistik paritas tidak memiliki hubungan dengan pemilihan penggunaan MKJP. Sedangkan dukungan suami memiliki hubungan dengan pemilihan penggunaan MKJP. Saran untuk ibu pengguna $\mathrm{KB}$ diharapkan berperan aktif dalam upaya penggunaan kontrasepsi, terutama kontrasepsi jangka panjang.
\end{abstract}

Kata Kunci : dukungan suami, paritas, pemilihan penggunaan MKJP 


\section{PENDAHULUAN}

Keluarga berencana (KB) adalah suatu program yang dimaksudkan untuk mengantisipasi dampak negative dari ledakan penduduk dengan pengaturan kehamilan bagi pasangan usia subur. Program KB juga dimaksudkan untuk menekan angka ibu akibat '4 Terlalu', yaitu terlalu muda, terlalu sering, terlalu banyak, dan terlalu tua. Penurunan angka kematian ibu merupakan salah satu target dari Sustainable Development Goals (SDGs) (BKKBN, Provinsi Kalimantan Selatan, 2015).

Salah satu strategi dari pelaksanaan program KB sendiri tercantum dalam Rencana Pembangunan Jangka Menengah Nasional (RPJMN) tahun 2015-2019 adalah menurunnya laju pertumbuhan penduduk (LPP), menurunnya angka kelahiran total (TFR) per WUS, meningkatnya pemakaian kontrasepsi, menurunnya kebutuhan ber-KB yang tidak terpenuhi, menurunnya angka kelahiran pada remaja usia 15-19 tahun, dan menurunya kehamilan yang tidak diinginkan dari WUS (15-49 tahun) (BKKBN, 2016).

Di Indonesia berdasarkan pola pemilihan jenis alat kontrasepsi, sebagian besar peserta KB aktif memilih suntikan dan pil sebagai alat kontrasepsi bahkan sangat dominan (lebih dari 80\%) dibanding metode lainnya. KB aktif di antara PUS tahun 2017 sebesar 63,22\% disusul oleh suntikan (62,77\%), Pil $(17,24 \%)$, Kondom (1,22\%), IUD (7,15\%), Implan (6,99\%), MOW (2,78\%) dan MOP $(0,53 \%)$. Padahal suntikan dan pil termasuk dalam metode kontrasepsi jangka pendek sehingga tingkat efektifitas suntikan dan pil dalam pengendalian kehamilan lebih rendah dibandingkan jenis kontrasepsi lainnya. Berdasarkan metode KB, Provinsi tertinggi dengan peserta $\mathrm{KB}$ MKJP tertinggi terdapat di Bali $(39,14 \%)$, D.I Yogyakarta $(36,03 \%)$, dan Nusa Tenggara Timur (30,49). Sedangkan Kalimantan Tengah dan Kalimantan Selatan walaupun secara keseluruhan metode merupakan
Provinsi yang dengan cakupan KB aktif yang tinggi, namun pengguna MKJP yang sangat rendah (Profil Kesehatan Indonesia, 2017).

Berdasarkan data Kesehatan Keluarga (Kesga) Dinas Kesehatan wilayah Provinsi Kalimantan Selatan hasil pencapaian KB aktif sampai dengan Desember tahun 2018 untuk peserta KB aktif sebanyak $512402(80,42 \%)$ sedangkan peserta dengan rincian masing-masing pencapaian kontrasepsi pil sebanyak 171262 jiwa $(33,4 \%)$, suntik sebanyak 296695 jiwa $(57,9 \%)$, kondom sebanyak 6175 jiwa (1,2\%), AKDR sebanyak 10991 jiwa $(2,1 \%)$, implant sebanyak 21361 jiwa (4,2\%), MOW sebanyak 4811 jiwa $(0,9 \%)$, dan MOP sebanyak 1107 jiwa $(0,2 \%)$ (Dinas Kesehatan Provinsi Kalimantan Selatan, 2018).

Dari wilayah Kota Banjarmasin tahun 2018 untuk jumlah peserta KB aktif sebanyak $32276 \quad(80,50 \%)$, sedangkan peserta dengan rincian masingmasing pencapaian kontrasepsi pil sebanyak 11959 jiwa $(37,05 \%)$, suntik sebanyak 18323 jiwa $(56,8 \%)$, kondom sebanyak 276 jiwa (0,9\%), AKDR sebanyak 327 jiwa (1,0\%), impalan sebanyak 903 jiwa (2,8\%), MOW sebesar 317 jiwa $(1,0 \%)$, dan MOP sebanyak 171 jiwa $(0,5 \%)$ (Dinas Kesehatan Provinsi Kalimantan Selatan, 2018)

Sedangkan masyarakat pengguna KB aktif di Puskesmas Sungai Jingah tahun 2018 sebanyak 7539 peserta $(79,3 \%)$, terdiri dari kondom 177 peserta $(2,3 \%)$, pil sebanyak 3304 peserta (44\%), suntik sebanyak 3353 peserta $(44,5 \%)$, AKDR sebanyak 403 peserta $(5,3 \%)$, implant sebanyak 191 peserta $(2,5 \%)$, MOW sebanyak 87 peserta $(1,2 \%)$, dan MOP sebanyak 24 peserta $(0,3 \%)$. (Laporan Puskesmas Sungai Jingah, 2018).

Pengetahuan akseptor KB sangat erat kaitannya dengan pemilihan alat kontrasepsi, karena dengan adanya pengetahuan yang baik terhadap metode kontrasepsi tertentu akan merubah 
pandangan akseptor dalam memilih kontrasepsi yang paling sesuai dan efektif digunakan sehingga membuat pengguna KB lebih nyaman terhadap kontrasepsi tersebut, dan dengan pengetahuan yang baik akan alat kontrasepsi dapat menghindari kesalahan dalam pemilihan alat kontrasepsi dapat menghindari kesalahan dalam pemilihan alat kontrasepsi yang paling sesuai bagi pengguna itu sendiri (Mahmudah, L. T. N., \& Indrawati, F, 2015) Paritas seorang wanita, akan memberikan pengalaman dan pengetahuan, sehingga wanita dapat mengambil keputusan yang tepat tentang cara atau alat kontrasepsi yang akan dipakai. Pengetahuan responden tentang kontrasepsi dikelompok PUS pengguna non MKJP rata-rata lebih rendah bila dibandingkan tingkat pengetahuan responden di kelompok PUS pengguna MKJP. Hal tersebut kemungkinan dikarenakan kurang informasi tentang kontrasepsi jangka panjang (Fienalia, R. A., 2012). Maka dari itu, permasalahan tersebut melatar belakangi penelitian ini untuk mengetahui hubungan antara pengetahuan, paritas dan dukungan suami dengan pemilihan Metode Kontrasepsi Jangka Panjang (MKJP) Di Puskesmas Sungai Jingah Tahun 2019.

Tujuan pada penelitian ini adalah untuk mengetahui determinan pemilihan penggunaan Metode Kontrasepsi Jangka Panjang (MKJP) Di Puskesmas Sungai Jingah Tahun 2019. Dengan demikian penelitian ini dapat memberikan masukan dan memberi informasi yang benar tentang Metode Kontrasepsi Jangka Panjang (MKJP) bagi para Pasangan Usia Subur (PUS) sehingga dapat meningkatkan penggunaan MKJP pada Akseptor KB jangka panjang dan yang belum menggunakan KB jenis apapun.

\section{METODE PENELITIAN}

Penelitian ini menggunakan survei analitik dengan pendekatan Cross Sectional. (Notoatmodjo, S, 2012) Cross Sectional adalah suatu penelitian untuk mempelajari dinamika kolerasi antara faktor-faktor resiko dengan efek, dengan cara pendekatan observasi atau pengumpulan data sekaligus pada suatu saat (point time approach).

Populasi pada penelitian ini adalah seluruh ibu-ibu akseptor KB yang menggunakan salah satu metode kontrasepsi, yang berada di Puskesmas Sungai Jingah dari bulan Januari - Maret 2019 yang berjumlah 237 akseptor baru.

Besaran sampel menggunakan perhitungan rumus Slovin dan didapatkan hasil sebanyak 70 sampel. Pada penelitian ini teknik pengambilan sampel yang digunakan yaitu Non Probability Sampling dengan teknik Accidental Sampling yang pengambilan sampel berdasarkan kebetulan /insidental bertemu peneliti (Sugiyono, 2017). Penelitian yang digunakan untuk memenuhi data paritas dan dukungan suami dengan pemilihan penggunaan Metode Kontrasepsi Jangka Panjang (MKJP) Di Puskesmas Sungai Jingah Tahun 2019.

\section{HASIL DAN PEMBAHASAN}

Tabel 1. Karakteristik Responden Berdasarkan Pekerjaan, Pendidikan, dan Jenis KB di Puskesmas Sungai Jingah

\begin{tabular}{lcc}
\hline $\begin{array}{l}\text { Variabel } \\
\text { Penelitian }\end{array}$ & f & \% \\
\hline $\begin{array}{l}\text { Pekerjaan } \\
\text { Bekerja }\end{array}$ & 9 & 12,9 \\
Tidak Bekerja & 61 & 87,1 \\
\hline Pendidikan & & \\
$\quad$ Tinggi & 6 & 8,6 \\
Menengah & 29 & 41,4 \\
Dasar & 35 & 50 \\
\hline Jenis KB & & \\
Pil & 20 & 28,6 \\
Suntik & 39 & 55,7 \\
Implan & 3 & 4,3 \\
IUD & 5 & 7,1 \\
MOW & 2 & 2,9 \\
Kondom & 1 & 1,4 \\
\hline Total & $\mathbf{7 0}$ & $\mathbf{1 0 0 , 0}$ \\
\hline
\end{tabular}


Berdasarkan tabel 1 dapat diketahui bahwa sebagian responden yang bekerja berjumlah 9 orang $(12,9 \%)$, sedangkan yang tidak bekerja berjumlah 61 orang $(87,1 \%)$. Berdasarkan variabel pendidikan, diketahui bahwa sebagian besar responden memiliki pendidikan dasar sebanyak 35 orang $(50 \%)$ dan yang paling sedikit adalah pendidikan tinggi yaitu sebanyak 6 orang $(8,6 \%)$. Sedangkan variabel jenis $\mathrm{KB}$ diketahui bahwa sebagian besar responden banyak memilih menggunakan alat kontrasepsi suntik yaitu sebanyak 39 orang $(55,7 \%)$.

Tabel 2. Distribusi Frekuensi Responden Berdasarkan Pemilihan Penggunaan, Paritas \& Dukungan Suami Di Puskesmas Sungai Jingah

\begin{tabular}{lcc}
\hline Variabel Penelitian & f & $\mathbf{\%}$ \\
\hline Pemilihan Penggunaan & & \\
\hline Memilih & 10 & 14,3 \\
Tidak Memilih & 60 & 85,7 \\
\hline Paritas & & \\
Primipara & 22 & 31,4 \\
Multipara & 43 & 61,4 \\
Grandmultipara & 5 & 7,1 \\
\hline & & \\
\hline Dukungan Suami & & \\
Mendukung & 25 & 35,7 \\
Tidak Mendukung & 45 & 64,3 \\
\hline Total & $\mathbf{7 0}$ & $\mathbf{1 0 0}$ \\
\hline
\end{tabular}

Berdasarkan tabel 2 diketahui bahwa dari 70 responden, dalam variabel pemilihan penggunaan MKJP sebanyak 60 orang $(85,7 \%)$ akseptor $\mathrm{KB}$ banyak yang tidak memilih menggunakan MJKP. Berdasarkan variabel paritas diketahui bahwa sebagian besar responden memiliki status paritas multipara (lebih dari 1 anak) yaitu 43 orang $(61,4 \%)$. Sedangkan untuk variabel dukungan suami diketahui bahwa didapatkan sebanyak 45 orang $(64,3 \%)$ yang tidak memiliki dukungan suami.
Berdasarkan Tabel 3 diketahui bahwa responden yang memiliki kategori paritas primipara sebanyak 22 orang, yang terdiri dari responden yang memilih menggunakan Metode Kontrasepsi Jangka Panjang (MKJP) sebanyak 2 orang $(9,1 \%)$, dan responden yang tidak memilih menggunakan Metode Kontrasepsi Jangka Panjang (MKJP) sebanyak 20 orang $(90,9 \%)$. Sedangkan responden yang memiliki kategori paritas multipara dan grandmultipara sebanyak 48 orang, yang terdiri dari responden yang memilih menggunakan Metode Kontrasepsi Jangka Panjang (MKJP) sebanyak 8 orang $(16,7 \%)$, dan responden yang tidak memilih menggunakan Metode Kontrasepsi Jangka Panjang (MKJP) sebanyak 40 orang $(83,3 \%)$. Berdasarkan hasil uji statistik menggunakan chi square dengan uji alterntif yaitu Fisher's exact test didapatkan $p$ value $=0,488(p>0,05)$, dengan demikian dapat disimpulkan bahwa tidak ada hubungan yang bermakna antara paritas dengan pemilihan penggunaan Metode kontrasepsi Jangka Panjang (MKJP) Di Puskesmas Sungai Jingah.

Berdasarkan Tabel 3 diketahui bahwa responden yang memiliki kategori adanya dukungan suami sebanyak 25 orang, yang terdiri dari responden yang memilih menggunakan Metode Kontrasepsi Jangka Panjang (MKJP) sebanyak 8 orang (32\%), dan responden yang tidak memilih menggunakan Metode Kontrasepsi Jangka Panjang (MKJP) sebanyak 17 orang (68\%). Sedangkan responden yang memiliki kategori tidak adanya dukungan suami sebanyak 45 orang, yang terdiri dari responden yang memilih menggunakan Metode Kontrasepsi Jangka Panjang (MKJP) sebanyak 2 orang $(4,4 \%)$, dan responden yang tidak memilih menggunakan Metode Kontrasepsi Jangka Panjang (MKJP) sebanyak 43 orang (95,6\%). Berdasarkan hasil uji statistik menggunakan chi square dengan uji alternatif Fisher's exact test didapatkan $p$ value $=0,003(\mathrm{p}<0,05)$, dengan 
demikian dapat disimpulkan bahwa ada hubungan yang bermakna antara dukungan suami dengan pemilihan penggunaan Metode kontrasepsi Jangka Panjang (MKJP) Di Puskesmas Sungai Jingah.

Tabel 3. Hubungan Paritas dan Dukungan Suami dengan Pemilihan Penggunaan Metode Kontrasepsi Jangka Panjang (MKJP) di Puskesmas Sungai Jingah

\begin{tabular}{|c|c|c|c|c|c|c|c|}
\hline \multirow{3}{*}{ Variabel Penelitian } & \multicolumn{6}{|c|}{ Pemilihan Penggunaan MJKP } & \multirow[t]{3}{*}{$p$-value } \\
\hline & \multicolumn{2}{|c|}{ Memilih } & \multicolumn{4}{|c|}{ Tidak Memilih } & \\
\hline & $\mathrm{n}$ & $\%$ & $\mathrm{n}$ & $\%$ & $\mathrm{~N}$ & $\%$ & \\
\hline \multicolumn{8}{|l|}{ Paritas } \\
\hline Primipara & 2 & 9,1 & 20 & 90,9 & 22 & 100 & \multirow{2}{*}{0,488} \\
\hline $\begin{array}{l}\text { Multipara dan } \\
\text { Grandmultipara }\end{array}$ & 8 & 16,7 & 40 & 83,3 & 48 & 100 & \\
\hline \multicolumn{8}{|l|}{ Dukungan Suami } \\
\hline Mendukung & 8 & 32 & 17 & 68 & 25 & 100 & \multirow{2}{*}{0,003} \\
\hline Tidak Mendukung & 2 & 4,4 & 43 & 95,6 & 45 & 100 & \\
\hline Total & & & & & 70 & & \\
\hline
\end{tabular}

\section{PEMBAHASAN \\ Univariat}

Setelah

diketahui bahwa sebagian besar responden banyak yang tidak memilih MKJP yaitu sebanyak 60 orang $(85,7 \%)$. Hal ini dikarenakan dari 70 responden terdapat 54 orang responden masih berada di masa reproduksi yaitu sekitar 15-35 tahun, karena masih berada di masa reproduksi maka mereka banyak yang tidak memilih MKJP sebab kemungkinan mereka ingin memiliki anak lagi. menggunakan MKJP dibandingkan dengan non MKJP lebih efesien karena dapat dipakai dalam waktu lama serta lebih aman dan efektif serta lebih mudah karena pemasangannya dilakukan sekali dalam beberapa tahun sesuai dengan efektifitas penggunaannya.

Berdasarkan status paritas responden di Puskesmas Sungai Jingah, diketahui bahwa banyak dari responden memiliki paritas multipara (lebih dari 1 anak) yaitu sebanyak 43 orang $(61,4 \%)$. Jumlah anak tidak hanya mempengaruhi pemilihan MKJP, tetapi pengetahuan dan umur saat memperoleh anak dapat menjadi faktor yang dapat mempengaruhi keputusan memilih MKJP sebagai alat kontrasepsi. Kurangnya pengetahuan dan komunikasi dengan akseptor lain maupun petugas KB menjadikan akseptor kurang informasi tentang MKJP. Paritas atau jumlah kelahiran mempengaruhi keputusan PUS untuk menggunakan jenis atau metode kontrasepsi yang akan digunakan, paritas multipara berisiko terhadap resiko kelahiran yang akan terjadi (Yanti, 2011). Berdasarkan data kuesioner, bahwa ibu yang menggunakan MKJP, sebagian besar memiliki paritas multipara di banding ibu yang paritasnya primipara.

Berdasarkan dukungan suami, sebagian besar dari responden tidak memiliki dukungan suami yaitu sebanyak 45 orang $(64,3 \%)$. Dukungan suami dalam penggunaan kontrasepsi dapat berupa perencanaan jumlah anak yang diinginkan, dukungan suami dalam mengantar istri melakukan pemasangan atau pengontrolan, dukungan suami dalam menyediakan dana atau biaya yang dikeluarkan untuk memasang kontrasepsi, dan saran yang diberikan suami untuk menggunakan salah satu alat kontrasepsi. Pendapat suami mengenai keluarga berencana sangat kuat 
pengaruhnya untuk menentukan penggunaan metode keluarga oleh istri. Pada penelitian di lima kota di Indonesia, persetujuan suami merupakan faktor yang paling penting dalam menentukan apakah isteri akan menggunakan kontrasepsi atau tidak karena suami dipandang sebagai pelindung, pencari nafkah rumah tangga, dan pembuat keputusan (Roesli, 2008).

\section{Bivariat}

Berdasarkan hasil analisis statistik dengan uji Chi Square menggunakan uji alternatif Fisher's Exact Test didapat ( $p$ value $=0,488$ ) dengan demikian bisa dikatakan bahwa tidak ada hubungan antara paritas dengan pemilihan penggunaan Metode Kontrasepsi Jangka Panjang (MKJP). Responden yang memiliki anak lebih dari 2 orang mempunyai kemungkinan 20 kali lebih besar menggunakan MKJP di banding ibu yang mempunyai anak kurang dari 2 orang anak. Penelitian ini sejalan dengan dengan penelitian Laras Tsany Nur Mahmudah (2015) yang menyatakan bahwa tidak ada hubungan antara paritas dengan pemilihan MKJP $p$ value $=0,529>a=0,05$. Hasil tersebut juga sejalan dengan penelitian di Puskesmas Lendah 1 Kulon Progo yang menyatakan tidak ada hubungan antara Paritas dengan MKJP (Dewi, P. S., Daryanti, M. S., \& Sudyasih, $\mathrm{T}, 2017)$. Jumlah anak yang dimiliki, akan memberikan pengetahuan dan pengalaman sehingga wanita dapat mengambil keputusan yang tepat tentang cara atau alat kontrasepsi yang akan dipakai.

Hasil uji statistik dengan menggunakan uji Chi Square, Fisher's Exact Test didapatkan hasil nilai signifikan $p$ value $=$ $0,003<a=0,05$, sehingga dapat dinyatakan bahwa ada hubungan antara dukungan suami dengan pemilihan penggunaan Metode Kontrasepsi Jangka Panjang (MKJP) di Puskesmas Sungai Jingah. Berdasarkan uji Risk Estimate didapatkan nilai Odds Ratio (OR) sebesar 10.118. Artinya, akseptor yang tidak mendapatkan dukungan dari suami memiliki peluang untuk memilih Metode Kontrasepsi Jangka Panjang (MKJP) sebesar 10.118 kali lebih besar dibandingkan dengan akseptor yang mendapat dukungan dari suami. Penelitian ini sejalan dengan penelitian Laras Tsany Nur Mahmudah (2015) yang menyatakan bahwa ada hubungan antara dukungan suami dengan pemilihan penggunaan MKJP $p$ value $=0,002<a=0,05$. Penelitian ini sejalan di Rowosari yang menyatakan bahwa ada hubungan antara dukungan suami dengan penggunaan kontrasepsi $p$ value $=0,001<a=0,05$.

\section{SIMPULAN}

Berdasarkan hasil penelitian dan pembahasan maka dapat disimpulkan bahwa sebagian besar responden yang tidak memilih menggunakan Metode Kontrasepsi Jangka Panjang (MKJP) di Puskesmas Sungai Jingah adalah sebanyak 60 orang (85.7\%), sebagian besar paritas tentang pemilihan penggunaan Metode Kontrasepsi Jangka Panjang (MKJP) di Puskesmas Sungai Jingah dengan jumlah tertinggi adalah kategori multipara (2-4 orang anak) sebanyak 43 orang (61.4\%), sebagian besar dukungan suami tentang pemilihan penggunaan Metode Kontrasepsi Jangka Panjang (MKJP) di Puskesmas Sungai Jingah dengan jumlah tertinggi adalah tidak mendukung yang berjumlah 45 orang $(64.3 \%)$.

Tidak ada hubungan antara paritas dengan pemilihan penggunaan Metode Kontrasepsi Jangka Panjang (MKJP) di Puskesmas Sungai Jingah $(p=0.488)$, Ada hubungan antara dukungan suami dengan pemilihan penggunaan Metode Kontrasepsi Jangka Panjang (MKJP) di Puskesmas Sungai Jingah $(p=0.003)$.

\section{SARAN}

Ibu pengguna $\mathrm{KB}$ atau responden diharapkan berperan aktif dalam upaya penggunaan kontrasepsi terutama pada 
kontrasepsi jangka panjang, karena ibu berperan penting dalam menekan pertumbuhan penduduk dan penelitian ini diharapkan dapat menambah wawasan tentang Metode Kontrasepsi Jangka Panjang (MKJP) untuk mengetahui lebih banyak manfaat dalam penggunaannya, yaitu dengan sering berkonsultasi dengan tenaga kesehatan tentang alat kontrasepsi yang cocok, manfaat dan cara memakainya (Dayanti, J. K., Soeharto, B. P., \& Adespin, D. A., 2018).

\section{DAFTAR PUSTAKA}

BKKBN, Provinsi Kalimantan Selatan, 2015. Profil Data Kependudukan Dan KB Nasional. Banjarmasin: BKKBN Banjarmasin.

BKKBN, 2016. Laporan Kinerja Instansi Pemerintah $2015 . \quad(p d f)$. s.1.:https://www.bkkbn.go.id/pcontent /uploads/LAKIP_BKKBN_2016.pdf.

Dayanti, J. K., Soeharto, B. P., \& Adespin, D. A., 2018. Faktor-Faktor Yang Berhubungan Dengan Penggunaan Metode Kontrasepsi Pada Pasangan Usia Subur Di Rowosari. Semarang: Doctoral dissertation, Faculty of Medicine, Universitas Diponegoro.

Dewi, P. S., Daryanti, M. S., \& Sudyasih, T, 2017. Hubungan Usia Dan Paritas Dengan Penggunaan Metode Kontrasepsi Jangka Panjang Pada Akseptor Baru Di Puskesmas Lendah 1 Kulon Progo Yogyakarta. Yogyakarta: Universitas Aisyiyah Yogyakarta.

Dinas Kesehatan Provinsi Kalimantan Selatan, 2018. Laporan Tahunan Kesehatan Keluarga. s.1.:s.n.

Fienalia, R. A., 2012. Faktor-faktor yang Berhubungan dengan Penggunaan Metode Kontrasepsi Jangka Panjang (MKJP) DI Wilayah Kerja Puskesmas Pancoran Mas Kota Depok Tahun 2011. Jakarta: Skripsi. Universitas Indonesia. .
Laporan Puskesmas Sungai Jingah, 2018. Laporan Tahunan Puskesmas Sungai Jingah. Banjarmasin: s.n.

Mahmudah, L. T. N., \& Indrawati, F, 2015. Analisis faktor yang berhubungan dengan pemilihan metode kontrasepsi jangka panjang (MKJP) pada akseptor KB Wanita di Kecamatan Banyubiru Kabupaten Semarang. Unnes Journal of Public Health, 4(3).

Notoatmodjo, S, 2012. Metodologi Penelitian Kesehatan. Jakarta: Rineka Cipta.

Profil Kesehatan Indonesia, 2017. ( $p d f)$. s.l.:http://www.depkes.go.id/resource s/download/pusdatin/profilkesehatan-indonesia/ProfilKesehatan-Indonesia-tahun-2017.pdf.

Roesli, U., 2008. Kontrasepsi Hormonal. Jakarta: Pustaka Bunda.

Sugiyono, 2017. Metode Penelitian Kuantitatif, Kualitatif dan $R \& D$. Bandung: Alfabeta.

Yanti, 2011. Buku Ajar Kesehatan Reproduksi. Yogyakarta: Pustaka Rihama. 